\title{
A Sensitive, Robust Method for Determining nNatural and Synthetic Hormones in Surface and Waste Waters by Continuous Solid Phase Extraction-Gas Chromatography-Mass Spectrometry
}

\author{
Safae Chafi \\ University of Jaen: Universidad de Jaen \\ Evaristo Ballesteros ( $\square$ eballes@ujaen.es) \\ University of Jaen: Universidad de Jaen https://orcid.org/0000-0002-4802-3477
}

\begin{abstract}
Research Article
Keywords: Natural and synthetic hormones, Water, Continuous solid phase extraction, Microwave-assisted derivatization, Gas chromatography-mass spectrometry.
\end{abstract}

Posted Date: October 22nd, 2021

DOI: https://doi.org/10.21203/rs.3.rs-928794/v1

License: (c) (1) This work is licensed under a Creative Commons Attribution 4.0 International License. Read Full License 


\section{Abstract}

One recent trend in Analytical Chemistry is to develop economical, fast green methods using minimal amounts of solvents to determine a variety of analytes spanning a wide range of physicochemical properties. In this work, we developed a sensitive, selective method for the simultaneous determination of thirteen natural and synthetic hormones present at the nanogram-per-liter level in various types of water by using continuous solid phase extraction in combination with gas chromatography and mass spectrometry (GC-MS). The target analytes were preferentially sorbed on an Oasis HLB sorbent column and eluted with acetone for derivatization with a mixture of $N, O-$ bis(trimethylsilyl) trifluoroacetamide and trimethylchlorosilane in a household microwave oven at $200 \mathrm{~W}$ for 4 min. Under optimum conditions, the ensuing method exhibited good linearity ( $r \geq 0.998)$, good precision (RSD $\leq 7 \%)$, high recoveries (92-103\%) and low detection limits $\left(0.01-0.3 \mathrm{ng} \mathrm{L}^{-1}\right)$. The method outperforms existing alternatives in robustness, sensitivity, throughput, flexibility - it allows both estrogens, progestogens and androgens to be determined simultaneously - and compliance with the principles of Green Chemistry. It was successfully used to analyze various types of water samples (mineral, tap, well, pond, swimming pool, river and waste) that were found to contain four estrogens (estrone, 17ß-estradiol, 17a-ethinylestradiol and hexestrol), two progestogens (testosterone, dihydrotestosterone) and one progestogen (progesterone) at concentrations ranging from 3.0 to $110 \mathrm{ng} \mathrm{L}^{-1}$.

\section{Introduction}

Human health and well-being are closely linked to environmental quality. The growing population urbanization and modernization in many countries have raised serious environmental problems. In recent years, the number of micropollutants released to the environment has increased massively. This has been especially so with endocrine disrupting chemicals (EDCs) reaching aquatic ecosystems, which have received growing attention from the international scientific community owing to their strong potential impacts on human and ecosystem health. According to a scientific statement of the Endocrine Society, EDCs can have deleterious effects on male and female reproduction, breast development and health, thyroid metabolism, weight, and prostate, neuroendocrine and cardiovascular functions (Diamanti-Kandarakis et al. 2009). Natural and synthetic hormones such as estrogens, progestogens and androgens, which are among the most important biologically active EDCs, are produced naturally in the mammal body or synthetically created for use in birth control pills, growth promoters for livestock and medical applications. Hormones can reach the aquatic environment through direct discharge, incomplete removal in wastewater treatment plants or agricultural runoff (Adeel et al. 2017). Some studies have revealed that steroid hormones can have adverse effects on aquatic organisms (e.g., fish feminization, infertility and the development of physical abnormalities) at concentrations similar to those found in the aquatic environment (a few nanograms per liter; Sumpter and Jobling 2013; Fent 2015).

Natural and synthetic hormones have been encountered in various types of aquatic samples including surface, ground, drinking and waste water (Fent 2015; Golovko et al. 2018; Shen et al. 2018; Zhang and Fent 2018).Also, the American Environmental Protection Agency (US EPA) has included five (norethindrone, estrone, 17ß-estradiol, 17a-ethinylestradiol and estriol) on their Final Fourth Contaminant Candidate Lists US EPA (EPA 2016) and three estrogens (17a-ethinylestradiol, 17ß-estradiol, and estrone) were recently added to the second "watch list" of substances for EU-wide monitoring in the field of water policy proposed by the European Union in Decision 2018/840/EU (EC 2018). However, detecting and monitoring of other classes of natural and synthetic hormones such as progestogens and androgens remains difficult, and their environmental risks poorly known as a result. This has raised the need to acquire high-quality data by monitoring hormone concentrations in the environment and led to these compounds being classified in a new group of EDCs of concern for environmental regulations worldwide (Bergman et al. 2013).

Developing sensitive, selective analytical methods for determining hormones in environmental water samples is made difficult by the typical complexity of samples resulting in matrix interferences and the usually very low analyte concentrations (subnanogram-per-liter level) in aquatic matrices hindering their measurement. This shortcoming can be circumvented by using various analytical procedures including preconcentration and clean-up by liquid-liquid extraction (LLE; Fredj et al. 2015) or solid phase extraction (SPE; Suri et al. 2012; Vega-Morales et al. 2012 ; Caban et al. 2015; Huysman et al. 2017; Golovko et al. 2018; Shen et al. 2018; Zhang and Fent 2018). SPE is an effective choice for preconcentrating analytes and increasing the sensitivity of analytical methods as a result. SPE sorbents are chosen according to the properties of the target analytes and the nature of the matrix. The most widely used sorbent for hormones is Oasis HLB, a hydrophilic-lipophilic copolymer of $N$-vinylpyrrolidone and divinylbenzene (Azzouz et al. 2010; Migowska et al. 2012 ; VegaMorales et al. 2012 ; Kumirska et al. 2015; Shen et al. 2018; Zhang and Fent 2018) that efficiently retains both polar and nonpolar compounds. Some authors, however, have used mesoporous silica functionalized with octadecyl groups (SBA-15-C18; Gañán et al. 2015) or the macroporous neutral sorbent lonPac NG1 (Guo et al. 2013) to extract natural and synthetic hormones from water. Also, other sample preparation techniques such solid phase microextraction (Aftafa et al. 2014), stir-bar sorptive extraction (Xu et al. 2014; Almeida 
and Nogueira 2015) and dispersive liquid-liquid microextraction (Chang and Huang 2010; Martín et al. 2015) have been used to determine hormones in water samples.

Chromatographies are the most widely used instrumental techniques for the simultaneous determination of steroid hormones in environmental water samples. Coupling gas chromatography (GC) or liquid chromatography (LC) to single (MS) or tandem mass spectrometry (MS/MS) provide good separation, sensitivity and limits of detection. The LC-MS and LC-MS/MS combinations are especially frequently used because they enable direct analysis without derivatization of the analytes (Vega-Morales et al. 2012; Guo et al. 2013; Aftafa et al. 2014; Martín et al. 2015; Huysman et al. 2017; Golovko et al. 2018; Shen et al. 2018). However, LC-MS/MS was found to be subject to stronger matrix interferences - and hence to exhibit reduced signal-to-noise ratios, stability and accuracy-than GC-MS and GC-MS/MS (Grover et al. 2009). GC-MS equipment is economical to purchase and maintain, and operationally simple, all of which make it an especially attractive tool for identifying and quantifying natural and synthetic hormones in environmental matrices (Migowska et al. 2012; Suri et al. 2012; Albero et al. 2013; Caban et al. 2015; Kumirska et al. 2015; Ben Sghaier et al. 2017). The GC-MS technique requires derivatizing the analytes in order to increase their volatility and thermal stability for improved chromatographic separation, and sensitive, selective detection. Hormones are usually derivatized by silylating their hydroxyl groups with N,O-bis(trimethylsilyl) trifluoroacetamide (BSTFA) (Hernando et al. 2004; Ben Sghaier et al. 2017) or $N$-methyl- $N$ (trimethylsilyl) trifluoroacetamide (MSTFA) (Huang et al. 2015).

The primary aims of this work were (a) to develop a robust, fast, sensitive analytical method for the simultaneous determination of natural and synthetic estrogens progestogens and androgens in environmental water samples; $(b)$ to optimize the experimental procedure for efficient automated solid phase extraction (SPE), complete, expeditious derivatization with a microwave oven and accurate quantification by gas chromatography-mass spectrometry (GC-MS); and (c) to use the proposed method for the analysis of environmental samples in order to confirm the presence of natural and synthetic hormones in various types of water samples (tap, well, pond, swimming pool, river, waste and bottled) collected in Spain and Morocco.

\section{Materials And Methods}

\subsection{Chemicals and reagents}

All analytical standards used were of the highest commercially available purity. The hormones (17ß-estradiol, estrone, 17aethinylestradiol, estriol, hexestrol, diethylstilbestrol, progesterone, 19-norethindrone, norgestrel, testosterone, dihydrotestosterone, androstenedione and pregnenolone) were all purchased from Sigma-Aldrich (Madrid, Spain) in the highest available purity. Chromatographic-grade solvents (acetone, methanol, ethanol, $n$-hexane, petroleum ether, acetonitrile and ethyl acetate), the derivatizing reagents [N,O-bis(trimethylsilyl) trifluoroacetamide (BSTFA) and trimethylchlorosilane (TMCS)] and triphenylphosphate were also purchased from Sigma-Aldrich. Hydrochloric acid (reagent-grade, $37 \% \mathrm{HCl}$ ) and sodium hydroxide $(\mathrm{NaOH})$ were obtained from Fluka (Madrid, Spain). Amberlite XAD-2 (particle size 20-60 $\mu \mathrm{m}$ ) and reversed phase silica with octadecyl functional groups (RP-C18, particle

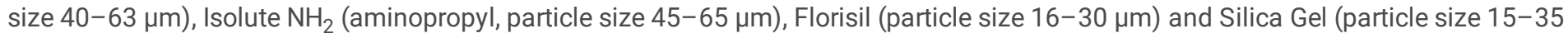
$\mu \mathrm{m}$ ) were equally obtained from Sigma-Aldrich. Oasis HLB (particle size 50-65 $\mu \mathrm{m}$ ) and LiChrolut EN (particle size 40-120 $\mu \mathrm{m}$ ) were supplied by Waters (Madrid, Spain) and Merck (Madrid, Spain), respectively.

Individual stock standards solutions of the target analytes at a concentration of $5 \mathrm{~g} \mathrm{~L}^{-1}$ were prepared in methanol -by exception, those of estrone and norgestrel were prepared in acetone in order to avoid crystallization. All standards solutions were stored in amber glassstoppered bottles at $4^{\circ} \mathrm{C}$. Also, all aqueous standards were prepared in ultrapure water from a Milli-Q apparatus (Millipore, Bedford, MA, USA).

\subsection{Equipment}

Hormones were identified and quantified by using a Focus gas chromatograph coupled to a DSQ II mass spectrometer equipped with an Al/AS 3000 autosampler and controlled by a computer running XCalibur software (Thermo Electron SA, Madrid, Spain). The instrument was equipped with a DB-5 fused silica capillary column (30 m, $0.25 \mathrm{~mm}$ i.d., $0.25 \mu \mathrm{m})$ coated with $5 \%$ phenylmethyl polysiloxane (Supelco, Madrid, Spain) for chromatographic separation with helium (purity 6.0) at a constant flow rate of $1 \mathrm{~mL} \mathrm{~min}^{-1}$ as the carrier gas. The temperature program was as follows: $130^{\circ} \mathrm{C}$ for $0.5 \mathrm{~min}, 40^{\circ} \mathrm{C} \mathrm{min}{ }^{-1}$ ramp to $240^{\circ} \mathrm{C}$, ramp to $280^{\circ} \mathrm{C}$ at $5^{\circ} \mathrm{C} \mathrm{min}{ }^{-1}$ and holding for 3.75 $\mathrm{min}$. The total analysis time for a GC run was $15 \mathrm{~min}$. The injector was operated in the splitless mode at a set temperature of $280^{\circ} \mathrm{C}$. The transfer line and ion source temperature was 280 and $200^{\circ} \mathrm{C}$, respectively, and the time for solvent delay set at 5 min. The mass range 
from 60 to 500 amu was used for full scan analysis. Data were acquired in the selected ion monitoring mode, using an ionization energy of $70 \mathrm{eV}$. The $\mathrm{m} / \mathrm{z}$ values for each analyte are listed in Table 1. Quantitation was based on peak areas relative to the internal standard (IS).

Table 1

Retention time, $\mathrm{pk}_{\mathrm{a}}, \log \mathrm{K}_{\mathrm{o} / \mathrm{w}}$, analytical figures of merit and mass values used to the determination of hormones in water samples by SPEGC-MS

\begin{tabular}{|c|c|c|c|c|c|c|c|c|c|c|c|}
\hline \multirow[t]{2}{*}{ Compounds } & \multirow[t]{2}{*}{$\mathrm{pK}_{\mathrm{a}}$} & \multirow{2}{*}{$\begin{array}{l}\text { Log } \\
\mathrm{K}_{\mathrm{o} / \mathrm{w}}\end{array}$} & \multirow{2}{*}{$\begin{array}{l}\text { Retention } \\
\text { time } \\
\text { (min) }\end{array}$} & \multirow{2}{*}{$\begin{array}{l}\text { Linear } \\
\text { range } \\
\text { (ng } \\
\mathrm{L}^{-1} \text { ) }\end{array}$} & \multirow{2}{*}{$\begin{array}{l}\text { Correlation } \\
\text { coefficient }\end{array}$} & \multirow{2}{*}{$\begin{array}{l}\text { LOD } \\
\text { (ng } \\
\mathrm{L}^{-} \\
\left.{ }^{1}\right)^{\mathrm{b}}\end{array}$} & \multicolumn{2}{|c|}{ Precision RSD (\%) } & \multicolumn{3}{|l|}{$\mathrm{m} / \mathrm{z}^{\mathrm{d}}$} \\
\hline & & & & & & & $\begin{array}{l}\text { Within- } \\
\text { day }\end{array}$ & $\begin{array}{l}\text { Between- } \\
\text { day }\end{array}$ & {$[\mathrm{M}]^{+}$. } & $\begin{array}{l}{[\mathrm{M}-} \\
15]^{+}\end{array}$ & $\begin{array}{l}\text { Additional } \\
\text { ions }\end{array}$ \\
\hline \multicolumn{12}{|l|}{ Estrogens } \\
\hline Hexestrol & 9.90 & 5.10 & 7.91 & $\begin{array}{l}0.04- \\
800\end{array}$ & 0.9997 & 0.01 & 4.6 & 6.8 & 414 & 399 & 207,179 \\
\hline Diethylstilbestrol & 9.13 & 5.10 & 7.99 & $\begin{array}{l}0.40- \\
800\end{array}$ & 0.9998 & 0.10 & 3.0 & 4.9 & 412 & 397 & 383,217 \\
\hline Estrone & 10.20 & 3.69 & 11.05 & $\begin{array}{l}0.04- \\
800\end{array}$ & 0.9993 & 0.01 & 4.2 & 6.8 & 342 & 327 & 218,257 \\
\hline 17ß-estradiol & 10.27 & 4.13 & 11.31 & $\begin{array}{l}0.04- \\
800\end{array}$ & 0.9982 & 0.01 & 3.5 & 7.0 & 416 & 401 & 285,326 \\
\hline 17a-ethinylestradiol & 10.24 & 4.25 & 12.62 & $\begin{array}{l}0.04- \\
800\end{array}$ & 0.9992 & 0.01 & 5.3 & 6.8 & 440 & 425 & 232,300 \\
\hline Estriol & 10.25 & 2.52 & 13.73 & $\begin{array}{l}0.04- \\
800\end{array}$ & 0.9992 & 0.01 & 5.5 & 7.0 & 504 & 489 & 147,311 \\
\hline \multicolumn{12}{|l|}{ Androgens } \\
\hline Testosterone & 15.06 & 3.17 & 11.65 & $\begin{array}{l}0.50- \\
800\end{array}$ & 0.9998 & 0.15 & 3.9 & 6.2 & 360 & 345 & 270,226 \\
\hline Dihydrotestosterone & n.a. ${ }^{a}$ & 3.55 & 10.90 & $\begin{array}{l}0.50- \\
800\end{array}$ & 0.9992 & 0.15 & 4.1 & 5.9 & 362 & 347 & 129,272 \\
\hline Androstenedione & n.a. ${ }^{a}$ & 2.71 & 11.44 & $\begin{array}{l}1.00- \\
800\end{array}$ & 0.9996 & 0.30 & 3.9 & 6.1 & $286^{e}$ & - & 244,148 \\
\hline \multicolumn{12}{|l|}{ Progestogens } \\
\hline Progesterone & n.a. ${ }^{a}$ & 3.80 & 13.60 & $\begin{array}{l}0.18- \\
800\end{array}$ & 0.9981 & 0.05 & 3.7 & 4.5 & $314^{e}$ & - & 124,272 \\
\hline Norethindrone & 13.09 & 2.99 & 11.60 & $\begin{array}{l}1.00- \\
800\end{array}$ & 0.9997 & 0.30 & 5.5 & 6.7 & 370 & 355 & 231,298 \\
\hline Levorgestrel & 13.09 & 3.36 & 12.88 & $\begin{array}{l}0.18- \\
800\end{array}$ & 0.9998 & 0.05 & 4.1 & 4.6 & 384 & 369 & 355,281 \\
\hline \multicolumn{12}{|l|}{ Others } \\
\hline Pregnenolone & n.a. ${ }^{a}$ & 4.22 & 12.35 & $\begin{array}{l}0.35- \\
800\end{array}$ & 0.9995 & 0.10 & 4.0 & 4.7 & 388 & 373 & 129,298 \\
\hline \multicolumn{12}{|l|}{ aNot available } \\
\hline \multicolumn{12}{|l|}{${ }^{b}$ Limit of detection } \\
\hline \multicolumn{12}{|c|}{${ }^{\mathrm{C}}$ Relative standard deviation $(\mathrm{n}=12)$ for ultrapure water spiked with $5 \mathrm{ng} \mathrm{L}^{-1}$} \\
\hline $\begin{array}{l}{ }^{\mathrm{d}} \text { Base peaks used for } \\
\text { IS (triphenylphosphat }\end{array}$ & $\begin{array}{l}\text { quantific } \\
): 77,17\end{array}$ & $\begin{array}{l}\text { tion ar } \\
325,\end{array}$ & $\begin{array}{l}\text { boldfaced, } \\
6\end{array}$ & 1] $]^{+}$. ioni & ed mass, [M- & {[]$^{+}:$los } & of a $\mathrm{CH}_{3}$ & adical from & he $\mathrm{Si}(\mathrm{C}$ & $\left.\mathrm{H}_{3}\right)_{3} \mathrm{gr}$ & $\mathrm{up}, \mathrm{m} / \mathrm{z}$ for \\
\hline
\end{tabular}


The continuous solid phase extraction system consisted of a Gilson Minipuls-3 peristaltic pump (Villiers-le-Bel, France) fitted with poly(vinyl chloride) tubes, two Rheodyne 5041 injection valves (Cotati, CA, USA) and a laboratory-made PTFE sorption column ( $5 \mathrm{~cm}, 3$ $\mathrm{mm}$ id) containing $80 \mathrm{mg}$ of Oasis-HLB sorbent. The sorbent column, which was conditioned with $1 \mathrm{~mL}$ of methanol, $1 \mathrm{~mL}$ of acetone and $2 \mathrm{~mL}$ of purified water, remained useful for at least 2 months.

\subsection{Sampling}

Water samples (tap, mineral, well, pond, swimming pool, river and waste) were collected in precleaned $500 \mathrm{~mL}$ amber glass bottles at various locations in Spain and Morocco, stored refrigerated at $4^{\circ} \mathrm{C}$ and analyzed within 3 days after collection in all instances. Bottled mineral water samples of the most popular brands were purchased locally. Suspended materials in the samples, which could block the SPE column, were removed by passage through Millipore mixed cellulose ester membrane filters of $0.45 \mu \mathrm{m}$ pore size. All samples were adjusted to neutral $\mathrm{pH}$ by adding dilute $\mathrm{HCl}$ or $\mathrm{NaOH}$ as required.

\subsection{Sample treatment}

Samples were cleaned up and the target analytes preconcentrated by continuous solid phase extraction SPE (Fig. 1). A volume of $100 \mathrm{~mL}$ of sample or standard solution at pH 7 adjusted with $0.1 \mathrm{M} \mathrm{HCl}$ or $0.1 \mathrm{M} \mathrm{NaOH}$ and containing a $0.04-800 \mathrm{ng} \mathrm{L}^{-1}$ concentration of each

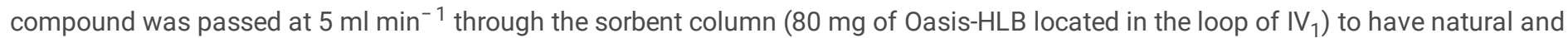
synthetic hormones immediately adsorbed and the sample matrix sent to waste. Then, the column was dried by passing an air stream at $5 \mathrm{~mL} \mathrm{\text {min}^{-1 }}$ before the second loop of $\mathrm{IV}_{2}$ was filled with $600 \mu \mathrm{L}$ of eluent (acetone containing a $500 \mathrm{ng} \mathrm{L}^{-1}$ concentration of triphenylphosphate as internal standard to avoid potential errors in measuring the final extract). Next, the column was eluted in the opposite direction of sample feeding. The organic extract was transferred into an air-tight $0.5 \mathrm{~mL}$ conical glass insert and evaporated to dryness under a gentle nitrogen stream. Samples should be thoroughly dried before derivatization in order to prevent the silylation reagents from interacting with moisture. The resulting dry residue was reconstituted with $70 \mu \mathrm{L}$ of a mixture of BSTFA $+1 \%$ TMCS (derivatizing reagent) and $35 \mu \mathrm{L}$ of petroleum ether. Then, the vials were closed and placed in a household microwave oven at $200 \mathrm{~W}$ for 4 min. After derivatization, $1 \mu \mathrm{L}$ aliquots were injected into the GC-MS system for analysis.

\section{Results And Discussion}

\subsection{Derivatization}

Derivatization is the most common and flexible choice for optimal chromatographic separation and MS measurement of analytes. The high polarity and thermal instability, and low molecular weight, of hormones can result in their easy adsorption on the chromatographic column or their decomposition at the injector port. This requires derivatizing them to increase their volatility and decrease their polarity and hence dipole-dipole interactions- prior to injection into GC-MS for their determination at trace (subnanogram-per-liter) levels, something that can be easily and rapidly accomplished by trimethylsilylation. In fact, this silylation treatment ensures completeness of reaction -and obtainment of a single main product- and conversion of all hydroxyl groups in the hormones (Kumirska et al. 2015; Ben Sghaier et al. 2017), all with adequate sensitivity and selectivity. The high volatility, low thermal degradation, fast reaction with compounds containing hydroxyl groups, and good solubility in common organic solvents of $\mathrm{N}, \mathrm{O}$-bis(trimethylsilyl)trifluoroacetamide led us to choose it as derivatization reagent, in combination with the catalyst trimethylchlorosilane for optimal derivatization of synthetic and natural hormones spanning a wide range of polarity (Hernando et al. 2004). Based on previous reports, BSTFA containing $1 \%$ TMCS is an excellent derivatization reagent for estrogens, androgens and progestogens (Zuo et al. 2007; Azzouz et al. 2010; Suri et al. 2012; Albero et al. 2013; Aftafa et al. 2014; Kumirska et al. 2015; Ben Sghaier et al. 2017).

Microwave irradiation has been found to reduce the time needed to derivatize analytes from several hours to a few minutes, especially with hormones (Zuo et al. 2007; Söderholm et al. 2010; Azzouz and Ballesteros 2012), provided the optimum conditions as regards solvent, irradiation time and microwave power are established. Using an effective solvent for the sample and derivatization products is important with a view to reducing the amount of silylating reagent needed and preventing hydrolysis of the products by exposure to moisture (Bowden et al. 2009). In this work, volumes of $50 \mu \mathrm{L}$ of individual solutions of the reagents were added to $100 \mu \mathrm{L}$ of a solution containing a $1 \mu \mathrm{g} \mathrm{L}^{-1}$ concentration of each analyte in ethyl acetate, acetonitrile, acetone, petroleum ether or $n$-hexane to identify the most suitable solvent. As can be seen from Fig. 2, the best results were obtained with petroleum ether, acetonitrile and ethyl acetate, the first being selected on the grounds of compatibility with the stationary phase of the chromatographic column -reportedly, the BSTFA-TMCS mixture shortens column lifetime-, sensitivity and stability (Albero et al. 2013). The influence of the volumes of solvent and derivatizing reagent was examined over the range $25-100 \mu \mathrm{L}$ and the best results were found to be provided by $35 \mu \mathrm{L}$ of petroleum ether and $70 \mu \mathrm{L}$ of BSTFA $+1 \%$ TMCS. 
The influence of the microwave irradiation conditions was examined by comparing the relative responses of all compounds with those obtained by using a water bath. For this purpose, a volume of $100 \mathrm{~mL}$ of aqueous sample containing a $100 \mathrm{ng} \mathrm{L}^{-1}$ concentration of each analyte was fed into the continuous system as described in Sect. 2.4. Then, the extract was evaporated to dryness under a gentle nitrogen stream and the dry residue reconstituted with $70 \mu \mathrm{L}$ of a mixture of BSTFA $+1 \%$ TMCS and $35 \mu \mathrm{L}$ of petroleum ether for further derivatization in the microwave oven at a variable power (100-400 W) and irradiation time (1-5 min). Using a power greater than $250 \mathrm{~W}$ was found to detract from the analytical signals, possibly as a result of degradation of the analytes, and so did using a power of $200 \mathrm{~W}$ or a time longer than $4 \mathrm{~min}$. By contrast, an irradiation power below $200 \mathrm{~W}$ resulted in poor derivatization. A microwave setting of $200 \mathrm{~W}$ and an irradiation time of $4 \mathrm{~min}$ were thus selected. By contrast, conventional thermal derivatization required heating at $60^{\circ} \mathrm{C}$ for $25 \mathrm{~min}$. Using the microwave oven for silylation thus reduced the reaction time from 25 min to only 4 min, which can be especially interesting for the fast derivatization of multiclass mixtures of hormones. In any case, progesterone and androstenedione could not be derivatized because they contained no hydroxyl groups for binding to $\mathrm{Si}\left(\mathrm{CH}_{3}\right)_{3}$ groups in the reagent, so they had to be determined underivatized.

\subsection{Solid phase extraction variables}

Selecting an appropriate sorbent for SPE was one of the most important tasks with a view to maximizing sorption efficiency and optimizing sample treatment. Optimization tests involved passing $100 \mathrm{~mL}$ of an aqueous standard solution containing a $100 \mathrm{ng} \mathrm{L}^{-1}$ concentration of each analyte at $\mathrm{pH} 7$, adjusted with dilute $\mathrm{NaOH}$ or $\mathrm{HCl}$, at $5 \mathrm{~mL} \mathrm{~min}{ }^{-1}$ through the sorbent column in triplicate. The sorbents included polymers (Amberlite XAD-2, Oasis HLB and LiChrolut EN), polar materials (Silica Gel and Florisil), reversed phase silica sorbents containing octadecyl groups (nonpolar) and Isolute NH2, all of which were used in amounts of $80 \mathrm{mg}$ to pack sorbent columns. The sorption efficiency of the sorbent materials was assessed by comparing the amounts of analytes present in $1 \mathrm{~mL}$ fractions of the aqueous solutions before ( $100 \%$ recovery) and after passage through the sorbent column (unsorbed analyte). Both fractions were collected in glass vials and evaporated to dryness under a gentle nitrogen stream for derivatization with $70 \mu \mathrm{L}$ of BSTFA $+1 \%$ TMCS mixture and $35 \mu \mathrm{L}$ of petroleum ether that was placed in a household microwave oven at $200 \mathrm{~W}$ for 4 min. Finally, $1 \mu \mathrm{L}$ aliquots of the treated solutions were injected into the GC-MS system for analysis. As can be seen from Table 2, the highest sorption efficiency, close to $100 \%$, for the analytes as a whole was achieved with Oasis HLB. By contrast, the efficiency of the other polymeric sorbents (LiChrolut EN, Amberlites XAD-2) and RP-C18 never exceeded $44 \%$ on average, that of Florisil and Isolute NH2 was lower than $18.2 \%$, and that of the polar sorbent (silica gel) even lower (6.6\% only).

Table 2

The sorption efficiency (\%) of the hormones on different sorbent materials.

\begin{tabular}{|llllllll|}
\hline Compound & Silica gel & LiChrolut EN & Oasis-HLB & Florisil & Amberlite XAD-2 & RP-C18 & IsoluteNH2 \\
\hline Hexestrol & 30.0 & 55.0 & 98 & 18 & 22 & 26,5 & 60 \\
\hline Diethylstilbestrol & 25,4 & 61.0 & 100 & 14 & 25,4 & 32 & 54,2 \\
\hline Dihydrotestosterone & 5.0 & 33.0 & 97 & 20 & 35 & 41 & 1 \\
\hline Estrone & 3,5 & 46,7 & 95 & 19,9 & 30,4 & 38 & 45,7 \\
\hline Androstenedione & 3 & 28.0 & 95 & 16 & 30 & 37 & 0 \\
\hline Norethindrone & 0 & 25,3 & 97 & 23 & 14,3 & 32,6 & 0 \\
\hline 17ß-estradiol & 5,8 & 41,6 & 100 & 9,7 & 27,6 & 28,7 & 0 \\
\hline Testosterone & 2.0 & 46.0 & 98 & 12 & 33 & 39 & 0 \\
\hline 17a-ethinyl estradiol & 11.0 & 58,9 & 100 & 27,8 & 46,6 & 36,9 & 76 \\
\hline Pregnenolone & 0 & 22.0 & 97 & 19,5 & 35 & 11 & 0 \\
\hline Levorgestrel & 0 & 28,7 & 95 & 17,7 & 32,9 & 18,1 & 0 \\
\hline Progesterone & 0 & 80,7 & 97 & 30,5 & 75,9 & 13,8 & 0 \\
\hline Estriol & 0 & 39,4 & 99 & 3,48 & 17,4 & 34,3 & 0 \\
\hline Sorption efficiency average & $\mathbf{6 . 6}$ & $\mathbf{4 3 . 6}$ & $\mathbf{9 7 . 5}$ & $\mathbf{1 7 . 8}$ & $\mathbf{3 2 . 7}$ & $\mathbf{2 9 . 9}$ & $\mathbf{1 8 . 2}$ \\
\hline
\end{tabular}

The organic solvents used as eluents differed in polarity and included methanol, ethanol, acetone, ethyl acetate and acetonitrile. Acetone resulted in the highest chromatographic peaks by effect of its increased eluting efficiency, the other solvents being roughly 1.5 times less 
efficient. Consequently, we chose to use acetone as eluent for all hormone classes.

The influence of the amount of Oasis-HLB was investigated by using various columns containing $20-120 \mathrm{mg}$ of sorbent. For this purpose, a series of calibration graphs were run for each hormone and column by passing $100 \mathrm{~mL}$ of aqueous standard solutions containing variable concentrations (5-500 $\mathrm{ng} \mathrm{L}^{-1}$ ) of each analyte and subsequently eluting the columns with $500 \mu \mathrm{L}$ of acetone. Analytical signals increased with increasing amount of sorbent up to $80 \mathrm{mg}$ and decreased above $90 \mathrm{mg}$ owing to the need for a higher volume of eluent to ensure complete elution of the hormones. A working column packed with $80 \mathrm{mg}$ of Oasis-HLB was thus used in subsequent tests.

Then, the influence of eluent volumes over the range 50-800 $\mu \mathrm{L}$ was investigated by using loops of variable length in the injection valve $\left(\mathrm{IV}_{2}\right.$ in Fig. 1). The desorption efficiency increased with increasing injected volume up to $600 \mu \mathrm{L}$, above which the signals for all analytes leveled off. The absence of carryover was confirmed by a second injection of $600 \mu \mathrm{L}$ of acetone. A single injection of $600 \mu \mathrm{L}$ of acetone therefore sufficed for complete elution of all hormones and that was the volume adopted as optimal.

Flow rates over the range 1-6 $\mathrm{mL} \mathrm{min}^{-1}$ for the sample during the preconcentration step and for air (eluent carrier) during elution had no effect on analyte sorption or elution efficiency. In fact, peaks areas remained constant throughout, which led us to choose 5 mL min ${ }^{-1}$ for both the sample and air in order to ensure a high throughput. An identical air flow rate was used to dry the sorbent column before elution.

The sample $\mathrm{pH}$ strongly influenced the efficiency with which the hormones were retained by the sorbent. Tests conducted over the $\mathrm{pH}$ range 3.0-9.0 by passing $100 \mathrm{~mL}$ of an aqueous standard solution containing a $100 \mathrm{ng} \mathrm{L}-1$ concentration of each hormone adjusted with dilute $\mathrm{HCl}$ or $\mathrm{NaOH}$ revealed that the best results were obtained at 6.5-7.5, so neutral pH (7.0) was selected for subsequent tests. By contrast, the ionic strength of the water samples, adjusted with potassium chloride, had no effect on the analytical signal up to $1.5 \mathrm{M}$.

The breakthrough volume is important in that it is directly related to preconcentration factors, so it influences limits of detection and quantification -and hence sensitivity. The impact of this variable was assessed by passing volumes of $10-300 \mathrm{~mL}$ of aqueous solutions containing a $100 \mathrm{ng} \mathrm{L}^{-1}$ concentration of each analyte at $\mathrm{pH} 7$ through the SPE unit. Volumes up to $200 \mathrm{~mL}$ resulted in no loss of analytes from the column and maximized the sorption efficiency for all analytes ( 100\%); higher volumes, however, decreased the sorption efficiency by effect of the sorbent being overloaded and/or the sample matrix being coeluted with the analytes. A sample volume of $100 \mathrm{~mL}$ was therefore selected that provided a concentration factor of 167 with $600 \mu \mathrm{L}$ of solvent.

\subsection{Analytical performance}

The proposed SPE-GC-MS method, depicted in Fig. 1, was used under the above-described optimum conditions to determine thirteen natural and synthetic hormones in various types of water to assess analyte detectability, linearity range, precision and recovery. Table 1 shows the resulting figures of merit. Validation tests involved spiking $100 \mathrm{~mL}$ samples of ultrapure water with a few microliters of standard solutions containing all the hormones at concentrations over the range $0.04-800 \mathrm{ng} \mathrm{L}^{-1}$ that were treated as described in Sect. 2.4 to construct calibration curves. Each calibration solution additionally contained a $500 \mathrm{ng} \mathrm{L}^{-1} \mathrm{concentration}$ of internal standard (triphenylphosphate). The equations for the standard curves were obtained by plotting analyte-to-internal standard peak area ratios against analyte concentrations. Linearity was excellent for all analytes (correlation coefficients were all higher than 0.9981 ). Limits of detection (LODs), defined as the analyte concentrations providing chromatographic peaks equal to three times the regression standard deviation, $S_{y} /{ }_{x}$, divided by the slope of the calibration graph, ranged from 0.01 to $0.30 \mathrm{ng} \mathrm{L}^{-1}$. LODs were also calculated as the lowest concentrations providing chromatographic signals three times higher than background noise. Tests on real samples aimed at determining LODs provided results similar to those for distilled water. The lower limit of the linear range was taken to be the limit of quantification (LOQ) and calculated as $3.3 \times$ LOD.

The precision of the proposed method was measured in terms of reproducibility and repeatability by calculating the within- and betweenday relative standard deviation (RSD), respectively, for 12 individual standard mixtures of ultrapure water containing three different concentrations of each hormone $\left(5,50\right.$ or $\left.200 \mathrm{ng} \mathrm{L}^{-1}\right)$. Analyses were performed on the same day (within-day precision) or on 7 different days (between-day precision). As can be seen from Table 1, precision was quite acceptable; thus, RSD values ranged from 3.0 to $5.5 \%$ for repeatability (within-day precision) and 4.5 to $7 \%$ for reproducibility (between-day precision). The good precision obtained can be ascribed to the use of automated SPE and an internal standard to correct chromatographic errors in terms of relative area (analyte-to-internal standard peak area ratio).

Accuracy in terms of standard deviation was checked by assessing analyte recovery from various types of water (drinking, mineral, river, swimming pool, well and waste) that were spiked with three different concentrations of each hormone $\left(5,50\right.$ or 200 ng $\left.L^{-1}\right)$ for analysis in 
triplicate $(n=3)$. Because many of the water samples studied contained some hormone, recoveries were calculated by subtracting previously quantified endogenous compounds from total contents. As can be seen from Table 3, all hormones were accurately identified; also, average recoveries were acceptable (92-103\%), which testifies to the applicability of the proposed method to any type of water sample -a result, no doubt, of the highly efficient SPE unit used to pretreat samples.

Table 3

Average recoveries of hormones spiked to water samples ${ }^{\mathrm{a}}$.

\begin{tabular}{|c|c|c|c|c|c|c|c|c|c|c|c|c|}
\hline \multirow[t]{2}{*}{ Hormones } & \multicolumn{2}{|l|}{ Tap } & \multicolumn{2}{|c|}{ Mineral } & \multicolumn{2}{|c|}{$\begin{array}{l}\text { Swimming } \\
\text { Pool }\end{array}$} & \multicolumn{2}{|l|}{ Well } & \multicolumn{2}{|l|}{ River } & \multicolumn{2}{|c|}{ Waste water } \\
\hline & $\begin{array}{l}5 \mathrm{ng} \\
\mathrm{L}^{-1}\end{array}$ & $\begin{array}{l}50 \mathrm{ng} \\
\mathrm{L}^{-1}\end{array}$ & $\begin{array}{l}5 \mathrm{ng} \\
\mathrm{L}^{-1}\end{array}$ & $\begin{array}{l}50 \mathrm{ng} \\
\mathrm{L}^{-1}\end{array}$ & $\begin{array}{l}5 \mathrm{ng} \\
\mathrm{L}^{-1}\end{array}$ & $\begin{array}{l}50 \mathrm{ng} \\
\mathrm{L}^{-1}\end{array}$ & $\begin{array}{l}5 \mathrm{ng} \\
\mathrm{L}^{-1}\end{array}$ & $\begin{array}{l}50 \mathrm{ng} \\
\mathrm{L}^{-1}\end{array}$ & $\begin{array}{l}5 \mathrm{ng} \\
\mathrm{L}^{-1}\end{array}$ & $\begin{array}{l}50 \mathrm{ng} \\
\mathrm{L}^{-1}\end{array}$ & $\begin{array}{l}5 \mathrm{ng} \\
\mathrm{L}^{-1}\end{array}$ & $\begin{array}{l}50 \mathrm{ng} \\
\mathrm{L}^{-1}\end{array}$ \\
\hline \multicolumn{13}{|l|}{ Estrogens } \\
\hline Hexestrol & $\begin{array}{l}101 \\
\pm 5\end{array}$ & $96 \pm 4$ & $\begin{array}{l}95 \pm \\
4\end{array}$ & $\begin{array}{l}103 \pm \\
5\end{array}$ & $\begin{array}{l}95 \pm \\
5\end{array}$ & $\begin{array}{l}101 \pm \\
4\end{array}$ & $\begin{array}{l}101 \\
\pm 4\end{array}$ & $98 \pm 5$ & $\begin{array}{l}99 \pm \\
5\end{array}$ & $\begin{array}{l}101 \pm \\
4\end{array}$ & $\begin{array}{l}98 \pm \\
5\end{array}$ & $\begin{array}{l}100 \pm \\
4\end{array}$ \\
\hline Diethylstilbestrol & $\begin{array}{l}92 \pm \\
4\end{array}$ & $99 \pm 4$ & $\begin{array}{l}100 \\
\pm 6\end{array}$ & $95 \pm 4$ & $\begin{array}{l}92 \pm \\
4\end{array}$ & $96 \pm 4$ & $\begin{array}{l}96 \pm \\
4\end{array}$ & $\begin{array}{l}102 \pm \\
4\end{array}$ & $\begin{array}{l}99 \pm \\
5\end{array}$ & $\begin{array}{l}100 \pm \\
5\end{array}$ & $\begin{array}{l}101 \\
\pm 5\end{array}$ & $97 \pm 4$ \\
\hline Estrone & $\begin{array}{l}99 \pm \\
4\end{array}$ & $97 \pm 4$ & $\begin{array}{l}94 \pm \\
6\end{array}$ & $\begin{array}{l}103 \pm \\
5\end{array}$ & $\begin{array}{l}95 \pm \\
4\end{array}$ & $99 \pm 6$ & $\begin{array}{l}96 \pm \\
4\end{array}$ & $98 \pm 5$ & $\begin{array}{l}101 \\
\pm 4\end{array}$ & $98 \pm 5$ & $\begin{array}{l}102 \\
\pm 4\end{array}$ & $95 \pm 5$ \\
\hline 17ß-estradiol & $\begin{array}{l}96 \pm \\
4\end{array}$ & $\begin{array}{l}101 \pm \\
6\end{array}$ & $\begin{array}{l}97 \pm \\
6\end{array}$ & $94 \pm 5$ & $\begin{array}{l}99 \pm \\
6\end{array}$ & $\begin{array}{l}101 \pm \\
5\end{array}$ & $\begin{array}{l}100 \\
\pm 4\end{array}$ & $99 \pm 5$ & $\begin{array}{l}101 \\
\pm 5\end{array}$ & $\begin{array}{l}101 \pm \\
4\end{array}$ & $\begin{array}{l}96 \pm \\
5\end{array}$ & $\begin{array}{l}102 \pm \\
5\end{array}$ \\
\hline 17a-ethinylestradiol & $\begin{array}{l}101 \\
\pm 5\end{array}$ & $92 \pm 5$ & $\begin{array}{l}99 \pm \\
5\end{array}$ & $92 \pm 4$ & $\begin{array}{l}97 \pm \\
6\end{array}$ & $93 \pm 3$ & $\begin{array}{l}101 \\
\pm 4\end{array}$ & $\begin{array}{l}101 \pm \\
4\end{array}$ & $\begin{array}{l}98 \pm \\
4\end{array}$ & $99 \pm 5$ & $\begin{array}{l}97 \pm \\
6\end{array}$ & $\begin{array}{l}102 \pm \\
4\end{array}$ \\
\hline Estriol & $\begin{array}{l}99 \pm \\
6\end{array}$ & $\begin{array}{l}100 \pm \\
5\end{array}$ & $\begin{array}{l}97 \pm \\
4\end{array}$ & $93 \pm 4$ & $\begin{array}{l}103 \\
\pm 7\end{array}$ & $97 \pm 5$ & $\begin{array}{l}101 \\
\pm 6\end{array}$ & $96 \pm 5$ & $\begin{array}{l}102 \\
\pm 5\end{array}$ & $\begin{array}{l}100 \pm \\
5\end{array}$ & $\begin{array}{l}102 \\
\pm 4\end{array}$ & $\begin{array}{l}100 \pm \\
5\end{array}$ \\
\hline \multicolumn{13}{|l|}{ Androgens } \\
\hline Testosterone & $\begin{array}{l}100 \\
\pm 4\end{array}$ & $98 \pm 4$ & $\begin{array}{l}99 \pm \\
6\end{array}$ & $95 \pm 6$ & $\begin{array}{l}100 \\
\pm 6\end{array}$ & $95 \pm 4$ & $\begin{array}{l}100 \\
\pm 4\end{array}$ & $\begin{array}{l}102 \pm \\
5\end{array}$ & $\begin{array}{l}97 \pm \\
4\end{array}$ & $96 \pm 4$ & $\begin{array}{l}101 \\
\pm 3\end{array}$ & $96 \pm 4$ \\
\hline Dihydrotestosterone & $\begin{array}{l}101 \\
\pm 4\end{array}$ & $\begin{array}{l}102 \pm \\
6\end{array}$ & $\begin{array}{l}98 \pm \\
4\end{array}$ & $\begin{array}{l}100 \pm \\
5\end{array}$ & $\begin{array}{l}97 \pm \\
4\end{array}$ & $96 \pm 4$ & $\begin{array}{l}97 \pm \\
4\end{array}$ & $92 \pm 4$ & $\begin{array}{l}96 \pm \\
4\end{array}$ & $\begin{array}{l}101 \pm \\
5\end{array}$ & $\begin{array}{l}98 \pm \\
4\end{array}$ & $\begin{array}{l}100 \pm \\
5\end{array}$ \\
\hline Androstenedione & $\begin{array}{l}99 \pm \\
5\end{array}$ & $96 \pm 4$ & $\begin{array}{l}100 \\
\pm 5\end{array}$ & $\begin{array}{l}102 \pm \\
4\end{array}$ & $\begin{array}{l}101 \\
\pm 5\end{array}$ & $93 \pm 4$ & $\begin{array}{l}92 \pm \\
4\end{array}$ & $94 \pm 4$ & $\begin{array}{l}98 \pm \\
4\end{array}$ & $99 \pm 4$ & $\begin{array}{l}99 \pm \\
4\end{array}$ & $97 \pm 4$ \\
\hline \multicolumn{13}{|l|}{ Progestogens } \\
\hline Progesterone & $\begin{array}{l}101 \\
\pm 5\end{array}$ & $97 \pm 6$ & $\begin{array}{l}98 \pm \\
5\end{array}$ & $95 \pm 4$ & $\begin{array}{l}100 \\
\pm 4\end{array}$ & $94 \pm 6$ & $\begin{array}{l}98 \pm \\
6\end{array}$ & $97 \pm 4$ & $\begin{array}{l}97 \pm \\
4\end{array}$ & $\begin{array}{l}100 \pm \\
4\end{array}$ & $\begin{array}{l}99 \pm \\
4\end{array}$ & $98 \pm 5$ \\
\hline Norethindrone & $\begin{array}{l}102 \\
\pm 5\end{array}$ & $95 \pm 4$ & $\begin{array}{l}102 \\
\pm 5\end{array}$ & $92 \pm 4$ & $\begin{array}{l}98 \pm \\
4\end{array}$ & $\begin{array}{l}100 \pm \\
5\end{array}$ & $\begin{array}{l}93 \pm \\
6\end{array}$ & $\begin{array}{l}102 \pm \\
5\end{array}$ & $\begin{array}{l}100 \\
\pm 5\end{array}$ & $\begin{array}{l}101 \pm \\
6\end{array}$ & $\begin{array}{l}99 \pm \\
6\end{array}$ & $\begin{array}{l}102 \pm \\
5\end{array}$ \\
\hline Levorgestrel & $\begin{array}{l}102 \\
\pm 5\end{array}$ & $93 \pm 4$ & $\begin{array}{l}102 \\
\pm 5\end{array}$ & $97 \pm 4$ & $\begin{array}{l}96 \pm \\
5\end{array}$ & $95 \pm 4$ & $\begin{array}{l}99 \pm \\
4\end{array}$ & $97 \pm 4$ & $\begin{array}{l}102 \\
\pm 5\end{array}$ & $99 \pm 4$ & $\begin{array}{l}99 \pm \\
5\end{array}$ & $\begin{array}{l}100 \pm \\
5\end{array}$ \\
\hline \multicolumn{13}{|l|}{ Others } \\
\hline Pregnenolone & $\begin{array}{l}98 \pm \\
4\end{array}$ & $\begin{array}{l}103 \pm \\
5\end{array}$ & $\begin{array}{l}99 \pm \\
5\end{array}$ & $94 \pm 5$ & $\begin{array}{l}101 \\
\pm 5\end{array}$ & $\begin{array}{l}100 \pm \\
5\end{array}$ & $\begin{array}{l}99 \pm \\
4\end{array}$ & $94 \pm 5$ & $\begin{array}{l}99 \pm \\
4\end{array}$ & $95 \pm 4$ & $\begin{array}{l}100 \\
\pm 4\end{array}$ & $97 \pm 5$ \\
\hline
\end{tabular}

\subsection{Determination of hormones in water}

The practical use of the proposed SPE-GC-MS method for determining hormones was assessed by applying it to various types of real waters samples (tap, mineral, well, swimming pool, pond, river and waste) from Spain and Morocco. Volumes of $100 \mathrm{~mL}$ of the different types of samples were analyzed by using the method in triplicate. All samples were passed through a $0.45 \mu \mathrm{m}$ membrane filter and adjusted to $\mathrm{pH} 7$ prior to insertion into the continuous SPE system. As can be seen from Table 4, none of the hormones was present in tap or mineral water. Also, norethindrone, levorgestrel, estriol, pregnenolone, diethylstilbestrol and androstenedione were detected in none of the samples. On the other hand, estrone was the natural estrogen most frequently detected in all other types of water (well, pond, 
swimming pool and river), but especially in river water (concentrations of 13-83 $\mathrm{ng} \mathrm{L}^{-1}$ ), which are similar to those of coated South Florida surface water, where it was encountered at levels up to $79.5 \mathrm{ng} \mathrm{L}^{-1}$ by $\mathrm{Ng}$ et al. (2021). One other hormone found in many samples was dihydrotestosterone $\left(28-64 \mathrm{ng} \mathrm{L}^{-1}\right)$. Also, testosterone was found in pond and river water, at concentrations from 6 to $24 \mathrm{ng}$ $\mathrm{L}^{-1}$. Ben Sghaier et al. (2017) found testosterone at levels from 5.4 to $6.5 \mathrm{ng} \mathrm{L}^{-1}$ in river water (Table 5). By contrast, other hormones such as $17 \beta$-estradiol, hexestrol, 17 a-ethinylestradiol and progesterone were found at lower levels $\left(3.0-12 \mathrm{ng} \mathrm{L}^{-1}\right)$ but still similar to those in surface waters reported by other authors (Ben Sghaier et al. 2017; Zhou et al. 2020). By way of example, Fig. 3 shows the chromatogram of a swimming pool water analyzed by the proposed method.

Table 4

Hormones found in water samples $\left( \pm S D, n g L^{-1}, n=3\right)$ using the proposed SPE-GC-MS method.

\begin{tabular}{|c|c|c|c|c|c|c|c|}
\hline Sample & Hexestrol & Estrone & $\begin{array}{l}17 \beta- \\
\text { estradiol }\end{array}$ & $\begin{array}{l}17 a- \\
\text { ethinylestradiol }\end{array}$ & Testosterone & Dihydrotestosterone & Progesterone \\
\hline Tap 1 & $\mathrm{nq}^{\mathrm{a}}$ & $\mathrm{nq}$ & $\mathrm{nq}$ & $\mathrm{nq}$ & $\mathrm{nq}$ & $\mathrm{nq}$ & $\mathrm{nq}$ \\
\hline Tap 2 & $\mathrm{nq}$ & $\mathrm{nq}$ & $\mathrm{nq}$ & $\mathrm{nq}$ & $\mathrm{nq}$ & $\mathrm{nq}$ & $\mathrm{nq}$ \\
\hline Mineral 1 & $\mathrm{nq}$ & $\mathrm{nq}$ & $\mathrm{nq}$ & $\mathrm{nq}$ & $\mathrm{nq}$ & $\mathrm{nq}$ & $\mathrm{nq}$ \\
\hline Mineral 2 & $\mathrm{nq}$ & $\mathrm{nq}$ & $\mathrm{nq}$ & $\mathrm{nq}$ & $\mathrm{nq}$ & $\mathrm{nq}$ & nq \\
\hline Well 1 & $\mathrm{nq}$ & $14 \pm 1$ & $\mathrm{nq}$ & $\mathrm{nq}$ & $\mathrm{nq}$ & $\mathrm{nq}$ & $\mathrm{nq}$ \\
\hline Well 2 & $\mathrm{nq}$ & $27 \pm 1$ & $3.3 \pm 0.2$ & $\mathrm{nq}$ & $\mathrm{nq}$ & $\mathrm{nq}$ & $\mathrm{nq}$ \\
\hline $\begin{array}{l}\text { Swimming pool } \\
1\end{array}$ & $5.1 \pm 0.3$ & $15 \pm 1$ & $\mathrm{nq}$ & $\mathrm{nq}$ & $\mathrm{nq}$ & $28 \pm 1$ & $\mathrm{nq}$ \\
\hline $\begin{array}{l}\text { Swimming pool } \\
2\end{array}$ & $3.0 \pm 0.2$ & $43 \pm 2$ & $\mathrm{nq}$ & $4.0 \pm 0.2$ & $\mathrm{nq}$ & $31 \pm 2$ & $13 \pm 1$ \\
\hline Ponq 1 & $\mathrm{nq}$ & $21 \pm 1$ & $\mathrm{nq}$ & $\mathrm{nq}$ & $\mathrm{nq}$ & $38 \pm 2$ & nq \\
\hline Ponq 2 & $\mathrm{nq}$ & $25 \pm 1$ & $3.6 \pm 0.2$ & $\mathrm{nq}$ & $6.0 \pm 0.3$ & $28 \pm 1$ & nq \\
\hline River 1 & $\mathrm{nq}$ & $13 \pm 1$ & $\mathrm{nq}$ & $\mathrm{nq}$ & $17 \pm 1$ & $42 \pm 2$ & $\mathrm{nq}$ \\
\hline River 2 & $\mathrm{nq}$ & $83 \pm 4$ & $\mathrm{nq}$ & $\mathrm{nq}$ & $24 \pm 1$ & $64 \pm 3$ & $\mathrm{nq}$ \\
\hline Waste 1 & $10 \pm 1$ & $\begin{array}{l}110 \pm \\
10\end{array}$ & $12 \pm 1$ & $12 \pm 0.1$ & $31 \pm 2$ & $76 \pm 4$ & $24 \pm 1$ \\
\hline Waste 2 & $14 \pm 1$ & $93 \pm 4$ & $22 \pm 1$ & $7.0 \pm 0.4$ & $57 \pm 3$ & $45 \pm 2$ & $16 \pm 1$ \\
\hline
\end{tabular}


Table 5

Comparison of the proposed method with existing alternatives for the determination of hormones in aqueous samples

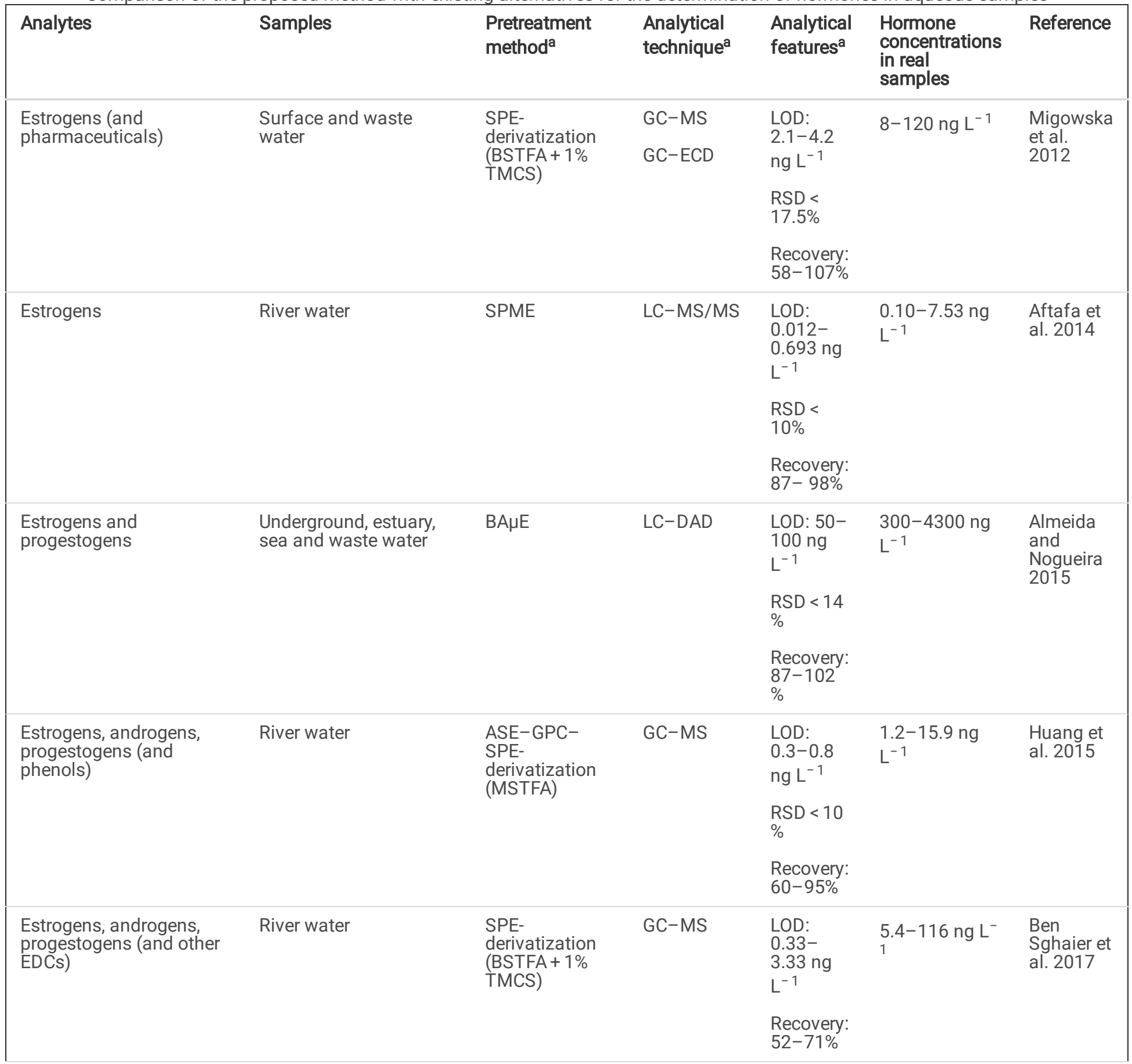

aASE-GPC: accelerated solvent extraction-automated gel permeation chromatography. BA $\mu \mathrm{E}$ : Bar adsorptive microextraction. BSTFA: N,O-bis(trimethylsilyl)trifluoroacetamide. GC-ECD: Gas chromatography with electron capture detection. GC-MS: Gas chromatography-mass spectrometry. GC-MS/MS: Gas chromatography-tandem mass spectrometry. LC-MS/MS: High performance liquid chromatography-tandem mass spectrometry. LC-DAD: High-performance liquid chromatography-diode array detection. LC-APCI/APPI-HRPS: Liquid chromatography tandem atmospheric pressure chemical ionization/atmospheric pressure photoionization with hybrid quadrupole/orbital trap mass spectrometry operated in the high resolution product scan mode. LCHRMS: Liquid chromatography-high resolution mass spectrometry. LC-MS/MS: Liquid chromatography-tandem mass spectrometry. LOD: Limit of detection. LOQ: Limit of quantification. MSTFA: $N$-methyl- $N$-(trimethylsilyl)trifluoroacetamide. ND: Not detected. RSD: Relative standard deviation. SPE: Solid-phase extraction. SPME: Solid-phase microextraction. TMCS:

Trimethylchlorosilane. UHPLC- HRMS: Ultrahigh performance liquid chromatography- high resolution mass spectrometry. UHPLCMS/MS: Ultra-high performance liquid chromatography-tandem mass spectrometry. UWWTPS: Urban wastewater treatment plants 


\begin{tabular}{|c|c|c|c|c|c|c|}
\hline Analytes & Samples & $\begin{array}{l}\text { Pretreatment } \\
\text { method }^{\mathrm{a}}\end{array}$ & $\begin{array}{l}\text { Analytical } \\
\text { technique }^{a}\end{array}$ & $\begin{array}{l}\text { Analytical } \\
\text { features }^{a}\end{array}$ & $\begin{array}{l}\text { Hormone } \\
\text { concentrations } \\
\text { in real } \\
\text { samples }\end{array}$ & Reference \\
\hline \multirow[t]{2}{*}{$\begin{array}{l}\text { Androgens, estrogens, } \\
\text { corticosteroids and } \\
\text { progestogens }\end{array}$} & Sea and fresh tap water & SPE & $\begin{array}{l}\text { UHPLC- } \\
\text { HRMS }\end{array}$ & $\begin{array}{l}\text { LOD: } \\
0.06-10 \\
\mathrm{ng} \mathrm{L}^{-1} \\
\text { RSD < } \\
10.5 \%\end{array}$ & $\begin{array}{l}0.26-39 \mathrm{ng} \mathrm{L}^{-} \\
1\end{array}$ & $\begin{array}{l}\text { Huysman } \\
\text { et al. } \\
2017\end{array}$ \\
\hline & & & & $\begin{array}{l}\text { Recovery: } \\
\text { 95-109\% }\end{array}$ & & \\
\hline \multirow[t]{3}{*}{$\begin{array}{l}\text { Natural and synthetic } \\
\text { progestogens }\end{array}$} & $\begin{array}{l}\text { Surface and waste } \\
\text { water }\end{array}$ & SPE & $\begin{array}{l}\text { LC- } \\
\text { APCI/APPI- } \\
\text { HRPS }\end{array}$ & $\begin{array}{l}\text { LOQ: } \\
0.02- \\
0.87 \mathrm{ng} \\
\mathrm{L}^{-1}\end{array}$ & $\begin{array}{l}0.14-110 \mathrm{ng} \\
\mathrm{L}^{-1}\end{array}$ & $\begin{array}{l}\text { Golovko } \\
\text { et al. } \\
2018\end{array}$ \\
\hline & & & & $\begin{array}{l}\mathrm{RSD}<33 \\
\%\end{array}$ & & \\
\hline & & & & $\begin{array}{l}\text { Recovery: } \\
60-140 \%\end{array}$ & & \\
\hline \multirow[t]{3}{*}{$\begin{array}{l}\text { Natural and synthetic } \\
\text { progestogens }\end{array}$} & $\begin{array}{l}\text { River and sewage } \\
\text { effluents }\end{array}$ & SPE & LC-MS/MS & $\begin{array}{l}\text { LOD: } \\
0.008- \\
0.12 \mathrm{ng} \\
\mathrm{L}^{-1}\end{array}$ & $\begin{array}{l}0.04-38 \mathrm{ng} \mathrm{L}^{-} \\
1\end{array}$ & $\begin{array}{l}\text { Shen et } \\
\text { al. } 2018\end{array}$ \\
\hline & & & & $\begin{array}{l}\text { RSD }< \\
17 \%\end{array}$ & & \\
\hline & & & & $\begin{array}{l}\text { Recovery: } \\
43-116 \%\end{array}$ & & \\
\hline
\end{tabular}

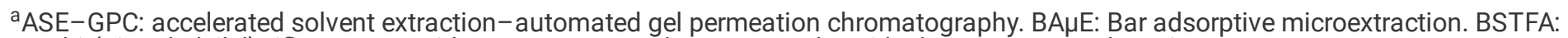
N,O-bis(trimethylsilyl)trifluoroacetamide. GC-ECD: Gas chromatography with electron capture detection. GC-MS: Gas chromatography-mass spectrometry. GC-MS/MS: Gas chromatography-tandem mass spectrometry. LC-MS/MS: High performance liquid chromatography-tandem mass spectrometry. LC-DAD: High-performance liquid chromatography-diode array detection. LC-APCI/APPI-HRPS: Liquid chromatography tandem atmospheric pressure chemical ionization/atmospheric pressure photoionization with hybrid quadrupole/orbital trap mass spectrometry operated in the high resolution product scan mode. LCHRMS: Liquid chromatography-high resolution mass spectrometry. LC-MS/MS: Liquid chromatography-tandem mass spectrometry. LOD: Limit of detection. LOQ: Limit of quantification. MSTFA: $N$-methyl- $N$-(trimethylsilyl)trifluoroacetamide. ND: Not detected. RSD: Relative standard deviation. SPE: Solid-phase extraction. SPME: Solid-phase microextraction. TMCS:

Trimethylchlorosilane. UHPLC- HRMS: Ultrahigh performance liquid chromatography- high resolution mass spectrometry. UHPLCMS/MS: Ultra-high performance liquid chromatography-tandem mass spectrometry. UWWTPs: Urban wastewater treatment plants 


\begin{tabular}{|c|c|c|c|c|c|c|}
\hline Analytes & Samples & $\begin{array}{l}\text { Pretreatment } \\
\text { method }^{\mathrm{a}}\end{array}$ & $\begin{array}{l}\text { Analytical } \\
\text { technique }^{a}\end{array}$ & $\begin{array}{l}\text { Analytical } \\
\text { features }^{a}\end{array}$ & $\begin{array}{l}\text { Hormone } \\
\text { concentrations } \\
\text { in real } \\
\text { samples }\end{array}$ & Reference \\
\hline \multirow[t]{2}{*}{$\begin{array}{l}\text { Androgens, estrogens, } \\
\text { corticosteroids and } \\
\text { progestogens }\end{array}$} & River and waste water & SPE & LC-MS/MS & $\begin{array}{l}\text { LOD: } \\
0.01-40 \\
\mathrm{ng} \mathrm{L}^{-1} \\
\text { RSD: } 1- \\
13 \%\end{array}$ & ${ }_{1}^{1.0-220 \mathrm{ng} \mathrm{L}^{-}}$ & $\begin{array}{l}\text { Zhang et } \\
\text { al. } 2018\end{array}$ \\
\hline & & & & $\begin{array}{l}\text { Recovery: } \\
56-126 \%\end{array}$ & & \\
\hline \multirow[t]{3}{*}{$\begin{array}{l}\text { Androgens, estrogens, } \\
\text { progestogens (and } \\
\text { bisphenol A) }\end{array}$} & $\begin{array}{l}\text { Tap, surface and waste } \\
\text { water }\end{array}$ & SPE & $\begin{array}{l}\text { UHPLC- } \\
\text { MS/MS }\end{array}$ & $\begin{array}{l}\text { LOD: } \\
0.05-1.0 \\
\mathrm{ng} \mathrm{L}^{-1}\end{array}$ & $\begin{array}{l}0.80-790 \mathrm{ng} \\
\mathrm{L}^{-1}\end{array}$ & $\begin{array}{l}\text { Goeury et } \\
\text { al. } 2019\end{array}$ \\
\hline & & & & $\begin{array}{l}\text { RSD: } \\
1.3-19 \%\end{array}$ & & \\
\hline & & & & $\begin{array}{l}\text { Recovery: } \\
70-130 \%\end{array}$ & & \\
\hline \multirow[t]{2}{*}{$\begin{array}{l}\text { Androgens, estrogens } \\
\text { and progestogens }\end{array}$} & $\begin{array}{l}\text { Surface and waste } \\
\text { water }\end{array}$ & SPE & LC-MS/MS & $\begin{array}{l}\text { LOD: } \\
1.9-44 \\
\mathrm{ng} \mathrm{L}^{-1}\end{array}$ & $1.9-384 \mathrm{ng} \mathrm{L}^{-}$ & $\begin{array}{l}\text { González } \\
\text { et al. } \\
2020\end{array}$ \\
\hline & & & & $\begin{array}{l}\text { Recovery: } \\
42-144 \%\end{array}$ & & \\
\hline \multirow[t]{3}{*}{$\begin{array}{l}\text { Androgens, estrogens, } \\
\text { progestogens (and other } \\
\text { EDCs) }\end{array}$} & Swimming pool water & SPE & LC-MS & $\begin{array}{l}\text { LOD: } \\
0.02- \\
0.28 \mathrm{ng} \\
\mathrm{L}^{-1}\end{array}$ & $\begin{array}{l}0.02-78.8 \mathrm{ng} \\
\mathrm{L}^{-1}\end{array}$ & $\begin{array}{l}\text { Zhou et } \\
\text { al. } 2020\end{array}$ \\
\hline & & & & $\begin{array}{l}\text { RSD < } \\
13.5 \%\end{array}$ & & \\
\hline & & & & $\begin{array}{l}\text { Recovery: } \\
72-118 \%\end{array}$ & & \\
\hline
\end{tabular}

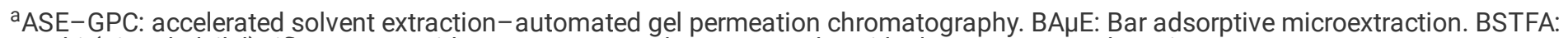
N,O-bis(trimethylsilyl)trifluoroacetamide. GC-ECD: Gas chromatography with electron capture detection. GC-MS: Gas chromatography-mass spectrometry. GC-MS/MS: Gas chromatography-tandem mass spectrometry. LC-MS/MS: High performance liquid chromatography-tandem mass spectrometry. LC-DAD: High-performance liquid chromatography-diode array detection. LC-APCI/APPI-HRPS: Liquid chromatography tandem atmospheric pressure chemical ionization/atmospheric pressure photoionization with hybrid quadrupole/orbital trap mass spectrometry operated in the high resolution product scan mode. LCHRMS: Liquid chromatography-high resolution mass spectrometry. LC-MS/MS: Liquid chromatography-tandem mass spectrometry. LOD: Limit of detection. LOQ: Limit of quantification. MSTFA: $N$-methyl- $N$-(trimethylsilyl)trifluoroacetamide. ND: Not detected. RSD: Relative standard deviation. SPE: Solid-phase extraction. SPME: Solid-phase microextraction. TMCS:

Trimethylchlorosilane. UHPLC- HRMS: Ultrahigh performance liquid chromatography- high resolution mass spectrometry. UHPLCMS/MS: Ultra-high performance liquid chromatography-tandem mass spectrometry. UWWTPs: Urban wastewater treatment plants 


\begin{tabular}{|c|c|c|c|c|c|c|}
\hline Analytes & Samples & $\begin{array}{l}\text { Pretreatment } \\
\text { method }^{\mathrm{a}}\end{array}$ & $\begin{array}{l}\text { Analytical } \\
\text { technique }^{a}\end{array}$ & $\begin{array}{l}\text { Analytical } \\
\text { features }^{\mathrm{a}}\end{array}$ & $\begin{array}{l}\text { Hormone } \\
\text { concentrations } \\
\text { in real } \\
\text { samples }\end{array}$ & Reference \\
\hline \multirow[t]{3}{*}{$\begin{array}{l}\text { Natural and synthetic } \\
\text { estrogens (and other } \\
\text { emerging pollutants) }\end{array}$} & $\begin{array}{l}\text { Surface water (river and } \\
\text { canal) }\end{array}$ & SPE & LC-HRMS & $\begin{array}{l}\text { LOD: } \\
0.2-10.5 \\
\mathrm{ng} \mathrm{L}^{-1}\end{array}$ & $\begin{array}{l}5.1-285 \mathrm{ng} \mathrm{L}^{-} \\
-\end{array}$ & $\begin{array}{l}\mathrm{Ng} \text { et al. } \\
2021\end{array}$ \\
\hline & & & & $\begin{array}{l}\text { RSD }<20 \\
\%\end{array}$ & & \\
\hline & & & & $\begin{array}{l}\text { Recovery: } \\
96-101 \%\end{array}$ & & \\
\hline \multirow[t]{3}{*}{$\begin{array}{l}\text { Androgens, estrogens, } \\
\text { progestogens and } \\
\text { pregnenolone }\end{array}$} & $\begin{array}{l}\text { Drinking, mineral, river, } \\
\text { swimming pool, well } \\
\text { and waste water }\end{array}$ & $\begin{array}{l}\text { SPE- } \\
\text { derivatization } \\
\text { (BSTFA + 1\% } \\
\text { TMCS) }\end{array}$ & $\mathrm{GC}-\mathrm{MS}$ & $\begin{array}{l}\text { LOD: } \\
0.01- \\
0.30 \mathrm{ng} \\
\mathrm{L}^{-1}\end{array}$ & $\begin{array}{l}3.0-104 \mathrm{ng} \\
\mathrm{L}^{-1}\end{array}$ & This work \\
\hline & & & & $\begin{array}{l}\text { RSD: } \\
3.0-7.0 \%\end{array}$ & & \\
\hline & & & & $\begin{array}{l}\text { Recovery: } \\
92-103 \%\end{array}$ & & \\
\hline \multicolumn{7}{|c|}{$\begin{array}{l}\text { aASE-GPC: accelerated solvent extraction-automated gel permeation chromatography. BApE: Bar adsorptive microextraction. BSTFA: } \\
\text { N,O-bis(trimethylsilyl)trifluoroacetamide. GC-ECD: Gas chromatography with electron capture detection. GC-MS: Gas } \\
\text { chromatography--mass spectrometry. GC-MS/MS: Gas chromatography-tandem mass spectrometry. LC-MS/MS: High } \\
\text { performance liquid chromatography-tandem mass spectrometry. LC-DAD: High-performance liquid chromatography-diode array } \\
\text { detection. LC-APCI/APPI-HRPS: Liquid chromatography tandem atmospheric pressure chemical ionization/atmospheric pressure } \\
\text { photoionization with hybrid quadrupole/orbital trap mass spectrometry operated in the high resolution product scan mode. LC- } \\
\text { HRMS: Liquid chromatography-high resolution mass spectrometry. LC-MS/MS: Liquid chromatography-tandem mass } \\
\text { spectrometry. LOD: Limit of detection. LOQ: Limit of quantification. MSTFA: N-methyl- } N \text {-(trimethylsilyl)trifluoroacetamide. ND: Not } \\
\text { detected. RSD: Relative standard deviation. SPE: Solid-phase extraction. SPME: Solid-phase microextraction. TMCS: } \\
\text { Trimethylchlorosilane. UHPLC- HRMS: Ultrahigh performance liquid chromatography- high resolution mass spectrometry. UHPLC- } \\
\text { MS/MS: Ultra-high performance liquid chromatography-tandem mass spectrometry. UWWTPs: Urban wastewater treatment plants }\end{array}$} \\
\hline
\end{tabular}

The waste water samples contained various estrogens (hexestrol, estrone, 17 $\beta$-estradiol and 17a-ethinylestradiol) at concentrations from 7.0 to $110 \mathrm{ng} \mathrm{L}^{-1}$. These results are consistent with previously reported values (Table 5) such as those of Migowska et al. (2012) and Goeury et al. (2019). The androgen concentrations in waste water were highest for dihydrotestosterone (45-76 $\left.\mathrm{ng} \mathrm{L}^{-1}\right)$, followed by testosterone (31-57 $\left.\mathrm{ng} \mathrm{L}^{-1}\right)$. Interestingly, these concentrations are lower than those found in Chinese waste water $\left(201 \mathrm{ng} \mathrm{L}^{-1} \mathrm{for}\right.$ dihydrotestosterone and $53.3 \mathrm{ng} \mathrm{L}^{-1}$ for testosterone; Yu et al. 2019) but higher than those in waste water from Argentina (33 $\mathrm{ng} \mathrm{L^{-1 }}$ for dihydrotestosterone and $16 \mathrm{ng} \mathrm{L}^{-1}$ for testosterone; Gonzalez et al. 2020). Progesterone, at 16-24 $\mathrm{ng} \mathrm{L}^{-1}$, was the only progestogen detected in waste water, these levels being considerably lower than those reported by Golovko et al. (2018): 0.11-110 ng L-1. By way of example, Fig. 3 shows the chromatograms of a swimming pool water and a waste water analyzed by the proposed method.

\section{Conclusion}

A fast, sensitive and chemically green method was successfully developed and validated for the simultaneous determination of three classes of natural and synthetic hormones (estrogens, androgens and progestogens) at trace levels in environmental waters. Using offline SPE in combination with GC-MS shortens analysis times to only $15 \mathrm{~min}$. The proposed method has a number of advantages such as the following:

1. Using a continuous SPE system to preconcentrate the analytes reduces the amount of sorbent needed for their retention (80 mg of Oasis HLB). Also, columns can be used at least 150 times and efficient sorption maintained with a minimal volume of organic solvent $(600 \mu \mathrm{L})$ in a closed system that avoids analytes losses and reduces the risk of sample contamination from the laboratory or the analyst.

2. Using microwave radiation in combination with a silylation reagent affords fast derivatization of a multiclass hormones mixture (4 min vs 25 min with conventional methods).

3. Precision (RSD values of 3.0-7.0\%), accuracy (recoveries of 92-103\%) and limits of detection $\left(0.01-0.30 \mathrm{ng} \mathrm{L}^{-1}\right.$ ) are much better than those of existing alternatives (Table 5). In fact, LODs are well below the limits set on the European Watch Lists (e.g., $0.035 \mathrm{ng} \mathrm{L}^{-}$ ${ }^{1}$ for $17 \mathrm{a}$-ethinylestradiol, and $0.4 \mathrm{ng} \mathrm{L}^{-1}$ for estrone and $17 \beta$-estradiol; EC (2018). 
4. Four estrogens (estrone, $17 \beta$-estradiol, 17a-ethinylestradiol and hexestrol), two progestogens (testosterone, dihydrotestosterone) and one progestogen (progesterone) at concentrations ranging from 3.0 to $110 \mathrm{ng} \mathrm{L}^{-1}$ have been found in the different types of water samples analyzed.

In summary, the proposed method is a good choice for the routine analysis of real water samples (drinking, mineral, well, swimming pool, pond, river and waste) for natural and synthetic hormones.

\section{Declarations}

Ethical Approval Not Applicable

Conflict of interest The authors declare that they have no conflict of interest.

Consent to participate The authors Safae Chafi and Evaristo Ballesteros give consent to participate.

Consent to publish The authors Safae Chafi and Evaristo Ballesteros give consent to publish.

Author contribution Conceptualization and optimization and validation of the method were performed by Safae Chafi and Evaristo Ballesteros. Safae Chafi made the original writing-draft. Evaristo Ballesteros carried out the writing-review, edition, funding acquisition and supervision.

Funding The authors acknowledge funding from Consejería de Economía, Conocimiento, Empresas y Universidad, Regional Government of Andalucía, Spain (Project Ref. PY2018-1211) partially supported by EU FEDER funds, and the Research Programme of the University of Jaen (Plan 2019-2020).

Competing interests The authors declare that they have no conflict of interest.

Availability of data and materials Not Applicable

\section{References}

1. Adeel M, Song X, Wang Y, Francis D, Yang Y (2017) Environmental impact of estrogens on human, animal and plant life: A critical review. Environ Int 99:107-119. https://doi.org/10.1016/j.envint.2016.12.010

2. Aftafa C, Pelit FO, Yalçinkaya EE, Turkmen H, Kapdan I, Nil Ertaş F (2014) lonic liquid intercalated clay sorbents for micro solid phase extraction of steroid hormones from water samples with analysis by liquid chromatography-tandem mass spectrometry. J Chromatogr A 1361:43-52. https://doi.org/10.1016/j.chroma.2014.07.095

3. Albero B, Sánchez-Brunete C, Miguel E, Pérez RA, Tadeo JL (2013) Analysis of natural-occurring and synthetic sexual hormones in sludge-amended soils by matrix solid-phase dispersion and isotope dilution gas chromatography-tandem mass spectrometry. $J$ Chromatogr A 1283:39-45. https://doi.org/10.1016/j.chroma.2013.01.113

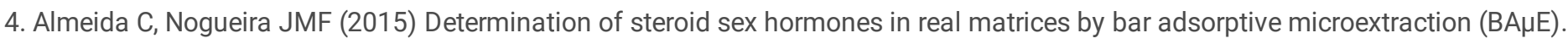
Talanta 136:145-154. https://doi.org/10.1016/j.talanta.2014.11.013

5. Azzouz A, Souhail B, Ballesteros E (2010) Continuous solid-phase extraction and gas chromatography-mass spectrometry determination of pharmaceuticals and hormones in water samples. J Chromatogr A 1217:2956-2963.

https://doi.org/10.1016/j.chroma.2010.02.069

6. Azzouz A, Ballesteros E (2012) Gas chromatography-mass spectrometry determination of pharmacologically active substances in urine and blood samples by use of a continuous solid-phase extraction system and microwave-assisted derivatization. $J$ Chromatogr B 891-892:12-19. https://doi.org/10.1016/j.jchromb.2012.02.013

7. Ben Sghaier R, Net S, Ghorbel-Abid I, Bessadok S, Le Coz M, Ben Hassan-Chehimi D, Trabelsi-Ayadi M, Tackx M, Ouddane B (2017) Simultaneous detection of 13 endocrine disrupting chemicals in water by a combination of SPE-BSTFA derivatization and GC-MS in Transboundary Rivers (France-Belgium). Water Air Soil Pollut 228:1-14. https://doi.org/10.1007/s11270-016-3195-2

8. Bergman A, Heindel JJ, Jobling S, Kidd KA, Zoeller RT (2013) State of the Science of Endocrine Disrupting Chemicals (2012) InterOrganization Programme for the Sound Management of Chemicals, United Nations Environment Programme and the World Health Organization. http://apps.who.int/iris/bitstream/handle/10665/78102/WHO_HSE_PHE_IHE_2013.1_eng.pdf . Accessed 16 September 2021

Page $14 / 18$ 
9. Bowden JA, Colosi DM, Stutts WL, Mora-Montero DC, Garrett TJ, Yost RA (2009) Enhanced analysis of steroids by gas chromatography/mass spectrometry using microwave-accelerated derivatization. Anal Chem. 81:6725-6734. https://doi.org/10.1021/ac900663c

10. Caban M, Lis E, Kumirska J, Stepnowski P (2015) Determination of pharmaceutical residues in drinking water in Poland using a new SPE-GC-MS(SIM) method based on Speedisk extraction disks and DIMETRIS derivatization. Sci Total Environ 538:402-411. https://doi.org/10.1016/j.scitotenv.2015.08.076

11. Chang CC, Huang SD (2010) Determination of the steroid hormone levels in water samples by dispersive liquid-liquid microextraction with solidification of a floating organic drop followed by high-performance liquid chromatography. Anal Chim Acta 662:39-43. https://doi.org/10.1016/J.ACA.2010.01.003

12. Diamanti-Kandarakis E, Bourguignon JP, Giudice LC, Hauser R, Prins GS, Soto AM, Zoeller RT, Gore AC (2009) Endocrine-disrupting chemicals: An Endocrine Society scientific statement. Endocr Rev 30:293-342. https://doi.org/10.1210/er.2009-0002

13. EC (2018) Commission implementing decision (EU) 2018/840 of 5 June 2018 establishing a watch list of substances for Union-wide monitoring in the field of water policy. Off J Eur Union L 141:9-12

14. EPA (2016) Contaminant Candidate List (CCL4) and Regulatory Determination, (n.d.). United States Environmental Protection Agency (US EPA). https://www.epa.gov/ccl/chemical-contaminants-ccl-4 . Accessed 16 September 2021

15. Fent K (2015) Progestins as endocrine disrupters in aquatic ecosystems: Concentrations, effects and risk assessment. Environ Int 84:115-130. https://doi.org/10.1016/j.envint.2015.06.012

16. Fredj S Ben, Nobbs J, Tizaoui C, Monser L (2015) Removal of estrone (E1), 17ß-estradiol (E2), and 17a-ethinylestradiol (EE2) from wastewater by liquid-liquid extraction. Chem Eng J 262:417-426. https://doi.org/10.1016/j.cej.2014.10.007

17. Gañán J, Morante-Zarcero S, Pérez-Quintanilla D, Sierra I (2015) A novel hybrid mesostructured silica for the solid-phase extraction of estrogenic hormones from waters. Anal Methods 7:4740-4749. https://doi.org/10.1039/c5ay00983a

18. Goeury K, Vo Duy S, Munoz G, Prévost M, Sauvé S (2019) Analysis of Environmental Protection Agency priority endocrine disruptor hormones and bisphenol $\mathrm{A}$ in tap, surface and wastewater by online concentration liquid chromatography tandem mass spectrometry. J Chromatogr A 1591:87-98. https://doi.org/10.1016/j.chroma.2019.01.016

19. Golovko O, Šauer P, Fedorova G, Kroupová HK, Grabic R (2018) Determination of progestogens in surface and waste water using SPE extraction and LC-APCI/APPI-HRPS. Sci Total Environ 621:1066-1073. https://doi.org/10.1016/j.scitotenv.2017.10.120

20. González A, Kroll KJ, Silva-Sanchez C, Carriquiriborde P, Fernandino JI, Denslow ND, Somoza GM (2020) Steroid hormones and estrogenic activity in the wastewater outfall and receiving waters of the Chascomús chained shallow lakes system (Argentina). Sci Total Environ 743:140401. https://doi.org/10.1016/j.scitotenv.2020.140401

21. Grover DP, Zhang ZL, Readman JW, Zhou JL (2009) A comparison of three analytical techniques for the measurement of steroidal estrogens in environmental water samples. Talanta 78:1204-1210. https://doi.org/10.1016/J.TALANTA.2008.12.049

22. Guo F, Liu Q, Qu GB, Song SJ, Sun JT, Shi JB, Jiang G B (2013) Simultaneous determination of five estrogens and four androgens in water samples by online solid-phase extraction coupled with high-performance liquid chromatography-tandem mass spectrometry. $J$ Chromatogr A 1281:9-18. https://doi.org/10.1016/j.chroma.2013.01.044

23. Hernando MD, Mezcua M, Gómez MJ, Malato O, Agüera A, Fernández-Alba AR (2004) Comparative study of analytical methods involving gas chromatography-mass spectrometry after derivatization and gas chromatography-tandem mass spectrometry for the determination of selected endocrine disrupting compounds in wastewaters. J Chromatogr A 1047:129-135. https://doi.org/10.1016/j.chroma.2004.06.123

24. Huang B, Sun WW, Li XM, Yang XX, Ren D, Wang Y, Pan XJ (2015) Simultaneous determination of progestogens, androgens, estrogens and phenols in water, sediment and biological samples by enolisation-silylation with ASE-GPC-SPE-GC/MS. Anal Methods 7:6139-6151. https://doi.org/10.1039/c5ay01050k

25. Huysman S, Van Meulebroek L, Vanryckeghem F, Van Langenhove H, Demeestere K, Vanhaecke L (2017) Development and validation of an ultra-high performance liquid chromatographic high resolution Q-Orbitrap mass spectrometric method for the simultaneous determination of steroidal endocrine disrupting compounds in aquatic matrices. Anal Chim Acta 984:140-150. https://doi.org/10.1016/j.aca.2017.07.001

26. Kumirska J, Migowska N, Caban M, Łukaszewicz P, Stepnowski P (2015) Simultaneous determination of non-steroidal anti-in fl ammatory drugs and oestrogenic hormones in environmental solid samples. Sci Total Environ 508:498-505. https://doi.org/10.1016/j.scitotenv.2014.12.020 
27. Martín J, Santos JL, Aparicio I, Alonso E (2015) Determination of hormones, a plasticizer, preservatives, perfluoroalkylated compounds, and a flame retardant in water samples by ultrasound-assisted dispersive liquid-liquid microextraction based on the solidification of a floating organic drop. Talanta 143:335-343. https://doi.org/10.1016/j.talanta.2015.04.089

28. Migowska N, Caban M, Stepnowski P, Kumirska J (2012) Simultaneous analysis of non-steroidal anti-inflammatory drugs and estrogenic hormones in water and wastewater samples using gas chromatography-mass spectrometry and gas chromatography with electron capture detection. Sci Total Environ 441:77-88. https://doi.org/10.1016/j.scitotenv.2012.09.043

29. Ng B, Quinete N, Maldonado S, Lugo K, Purrinos J, Briceño H, Gardinali P (2021) Understanding the occurrence and distribution of emerging pollutants and endocrine disruptors in sensitive coastal South Florida Ecosystems. Sci Total Environ 757:143720. https://doi.org/10.1016/j.scitotenv.2020.143720

30. Shen X, Chang H, Sun D, Wang L, Wu F (2018) Trace analysis of 61 natural and synthetic progestins in river water and sewage ef fluents by ultra-high performance liquid chromatography-tandem mass spectrometry. Water Res 133:142-152. https://doi.org/10.1016/j.watres.2018.01.030

31. Söderholm SL, Damm M, Kappe CO (2010) Microwave-assisted derivatization procedures for gas chromatography/mass spectrometry analysis. Mol Divers 14:869-888. https://doi.org/10.1007/s11030-010-9242-9

32. Sumpter JP, Jobling S (2013) The occurrence, causes, and consequences of estrogens in the aquatic environment. Environ Toxicol Chem 32:249-251. https://doi.org/10.1002/etc.2084

33. Suri RPS, Singh TS, Chimchirian RF (2012) Effect of process conditions on the analysis of free and conjugated estrogen hormones by solid-phase extraction-gas chromatography/mass spectrometry (SPE-GC/MS). Environ Monit Assess 184:1657-1669. https://doi.org/10.1007/s10661-011-2068-9

34. Vega-Morales T, Sosa-Ferrera Z, Santana-Rodríguez JJ (2012) Development and optimisation of an on-line solid phase extraction coupled to ultra-high-performance liquid chromatography-tandem mass spectrometry methodology for the simultaneous determination of endocrine disrupting compounds in wastewater samples. J Chromatogr A 1230:66-76. https://doi.org/10.1016/j.chroma.2012.01.077

35. Xu Z, Yang Z, Liu Z (2014) Development of dual-templates molecularly imprinted stir bar sorptive extraction and its application for the analysis of environmental estrogens in water and plastic samples. J Chromatogr A 1358:52-59. https://doi.org/10.1016/j.chroma.2014.06.093

36. Yu Q, Geng J, Ren H (2019) Occurrence and fate of androgens in municipal wastewater treatment plants in China. Chemosphere 237:124371. https://doi.org/10.1016/j.chemosphere.2019.124371

37. Zang K, Fent K (2018) Determination of two progestin metabolites (17a -hydroxypregnanolone and pregnanediol ) and different classes of steroids (androgens, estrogens, corticosteroids, progestins) in rivers and wastewaters by high-performance liquid chromatography-tandem mass spectrometry (HPLC-MS/MS). Sci Total Environ 610-611:1164-1172. https://doi.org/10.1016/j.scitotenv.2017.08.114

38. Zhou X, Peng F, Luo Z, Li Y, Li H, Yang Z (2020) Assessment of water contamination and health risk of endocrine disrupting chemicals in outdoor and indoor swimming pools. Sci Total Environ 704:135277. https://doi.org/10.1016/j.scitotenv.2019.135277

39. Zuo Y, Zhang K, Lin Y (2007) Microwave-accelerated derivatization for the simultaneous gas chromatographic-mass spectrometric analysis of natural and synthetic estrogenic steroids. J Chromatogr A 1148:211-218.

https://doi.org/10.1016/J.CHROMA.2007.03.037

\section{Figures}




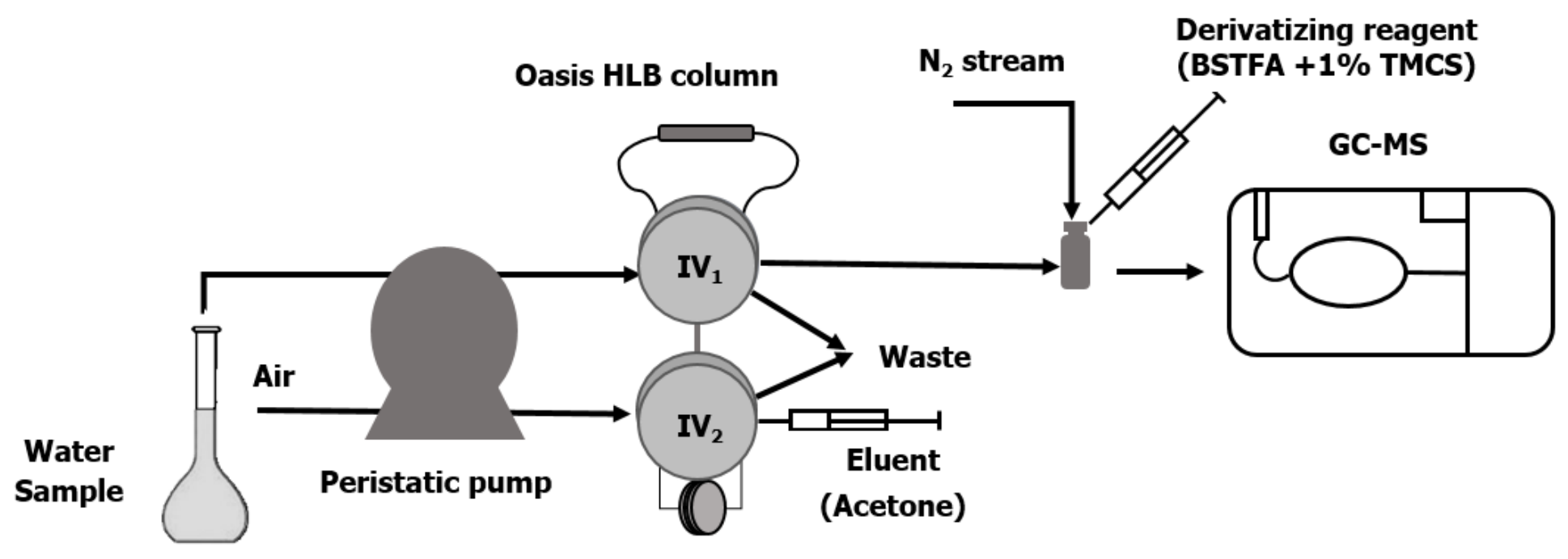

Figure 1

Continuous flow unit for the SPE extraction of hormones in water and their offline determination by gas chromatography. IV, injection valve; GC-MS, gas chromatograph-mass spectrometer.

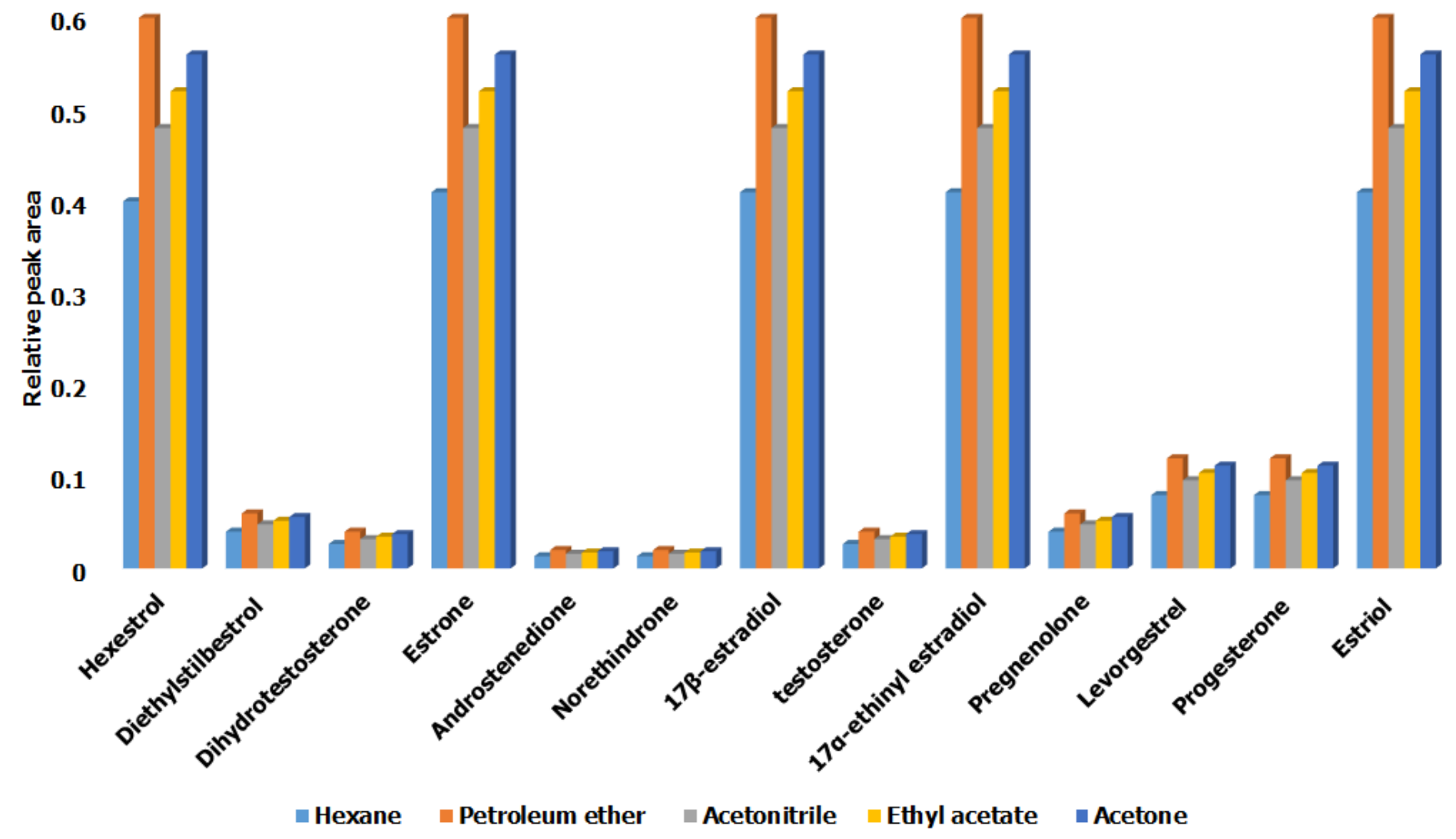

Figure 2

Influence of the reaction medium on the hormone derivatization reaction. 


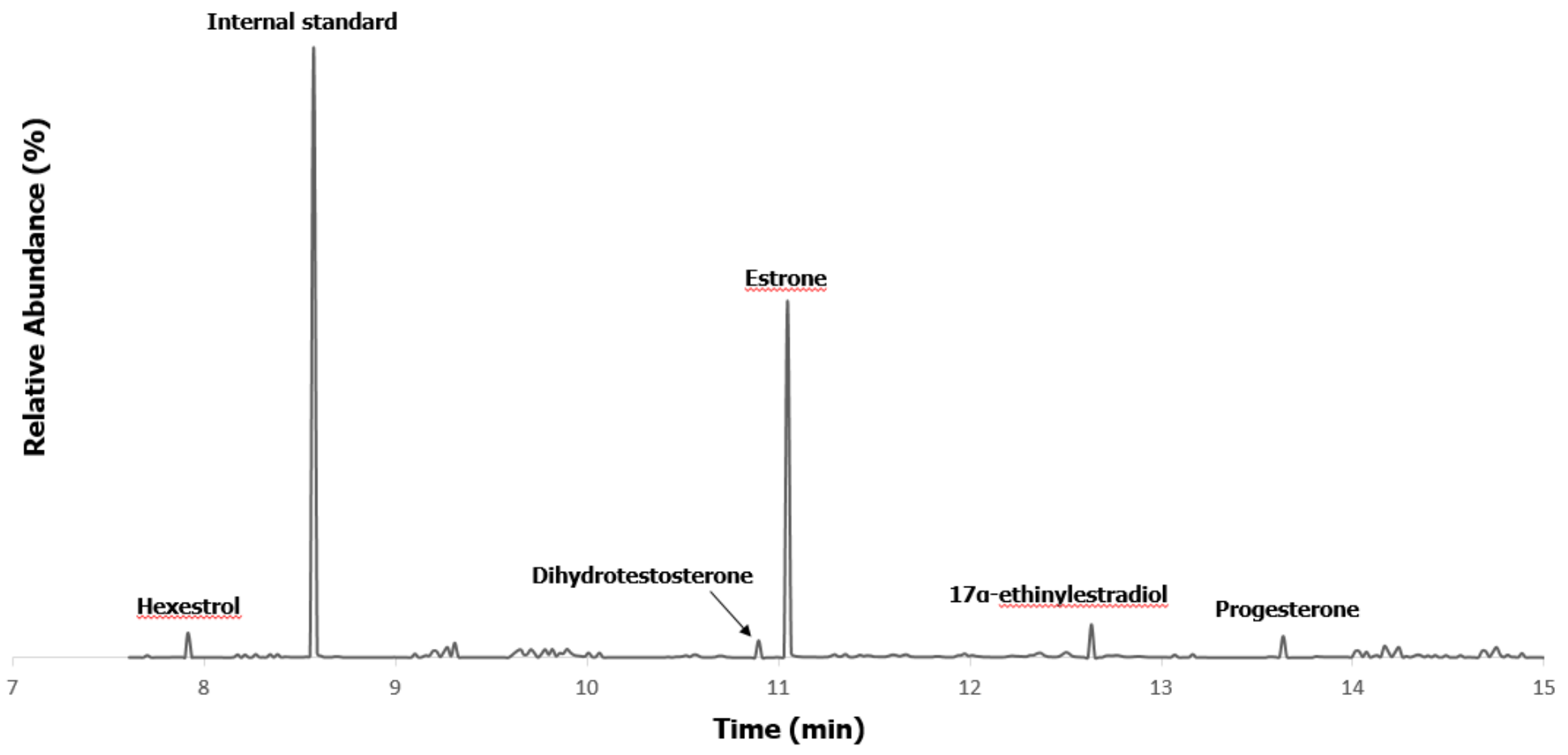

Figure 3

GC-MS chromatograms in the SIM mode for $100 \mathrm{~mL}$ of swimming pool water. 